\title{
Chemical Properties of Forest Soils from Romania's West Plain
}

\begin{abstract}
LUCIAN DINCA ${ }^{1}$, ION CHISALITA ${ }^{1,2}$, ILIE-COSMIN CANTAR ${ }^{1 *}$
1Marin Dracea National Institute for Research and Development in Forestry, 128 Eroilor Blvd., 128, Voluntari, Ilfov, Romania ${ }^{2}$ King Michael I of Romania Banat University of Agricultural Science and Veterinary Medicine from Timisoara, 119 Calea Aradului, 300645, Timisoara, Romania

The present paper characterizes the soils from Romania's West Plain from a chemical property point of view, based on data from forest management plans. As such, for each forest district, soil samples from characteristic forest areas are gathered once at ten years and then analyzed. In this manner, soil reaction, base saturation degree, total cationic exchange capacity, humus content and total nitrogen where analyzed and compared with results of soil analysis from other Romanian areas.
\end{abstract}

Keywords: Soil reaction, base saturation degree, humus content, total nitrogen

Besides its highly distinct orientation (predominantly on the North-South direction as opposed to the East-West direction of other Romanian plains, as it can be seen in Figure 1), the West Plain is distinguishable through an extraordinary horizontality, with the separation of some distinct altitudinal steps (levels) (high intermediary and low piedmont with a quasi-hollow divagation aspect), deep field mountain and sub mountain protrusions under the shape of river basins similar to fjords, strong and fragmented in the inter-fluvial sectors, some event with a graben aspect. Furthermore, the altitude is generally low (predominantly under $100 \mathrm{~m}$ ), the phreatic water level is close to the surface (generally ranging between 0.5 and $3 \mathrm{~m}$ ), while the soils are heavy, loamy, of a predominantly hydromorphic genesis, rarely automorphic, with a very low permeability and a defective hydrological regime (unpercolative) [1]. In this paper, analysis were realized with the purpose of characterizing the forest soils from Romania's West Plain in terms of chemical properties, such as: soil solution reaction, base saturation degree, total cationic exchange capacity, humus content and total nitrogen.

As such, in regard with soil solution reaction, soil $p \mathrm{H}$ is considered a key indicator of many soil chemical properties. The measure of dissociated hydrogen $\left(\mathrm{H}^{+}\right)$in the soil solution directly influences soil acidity and alkalinity, influencing a wide variety of soil conditions [2]. The soil pH has a decisive role also to immobilize (a basic $\mathrm{pH}$ ) or to allow the mobility (an acid pH) of heavy metals in soil [3].

Another studied chemical property is base saturation degree, which indicates the balance between acid and base cations adsorbed by a soil's cation exchange complex (CEC). The term is a partial misnomer, as a base is a chemical compound that can react with an acid to form a salt; calcium hydroxide, $\mathrm{Ca}(\mathrm{OH})_{2}$, is an appropriate example. In the present context, however, it takes the meaning of cation of the base, that is, $\mathrm{Ca}^{2+}$, as distinct from the $\mathrm{H}_{3} \mathrm{O}^{+}$and $\left[\mathrm{Al}\left(\mathrm{H}_{2} \mathrm{O}\right){ }_{6}\right]^{3+}$ cations, which are acids [4].

In the present paper, soils from Romania's West Plain were characterized under cationic exchange capacity, usually expressed in miliequivalents per $100 \mathrm{~g}$ of soil, which is a measure of the quantity of readily exchangeable cations neutralizing negative charge in the soil. These charges may be viewed as being balanced by either (i) an excess of opposite charge ions and a deficit (or negative adsorption) of similar charge ions, or (ii) the excess of opposite charge ions over those of similar charge [5].

Regarding the humus content, Stevenson (1972) affirms that humus represents less than $5 \%$ of the soil's dry weight and, furthermore, it imparts unique and remarkable properties to the inorganic sand, silt, and clay matrix. This aspect is to be regarded as a positive asset in crop production [6].

The total nitrogen from soils is composed of organic and inorganic nitrogen. Over $90 \%$ of the $\mathrm{N}$ in the surface layer of most soils is organically combined [7]. In regard with the inorganic nitrogen, Mulvaney (1996) asserts that most soils contain inorganic nitrogen $(\mathrm{N})$ in the form of ammonium $\left(\mathrm{NH}_{4}^{+}\right)$and nitrate $\left(\mathrm{NO}_{3}^{-}\right)$. Nitrite $\left(\mathrm{NO}_{2}{ }^{-}\right)$also may be present, but the amount is usually too small to warrant its determination, except for cases with $\mathrm{NH}_{4}^{+}$[8].

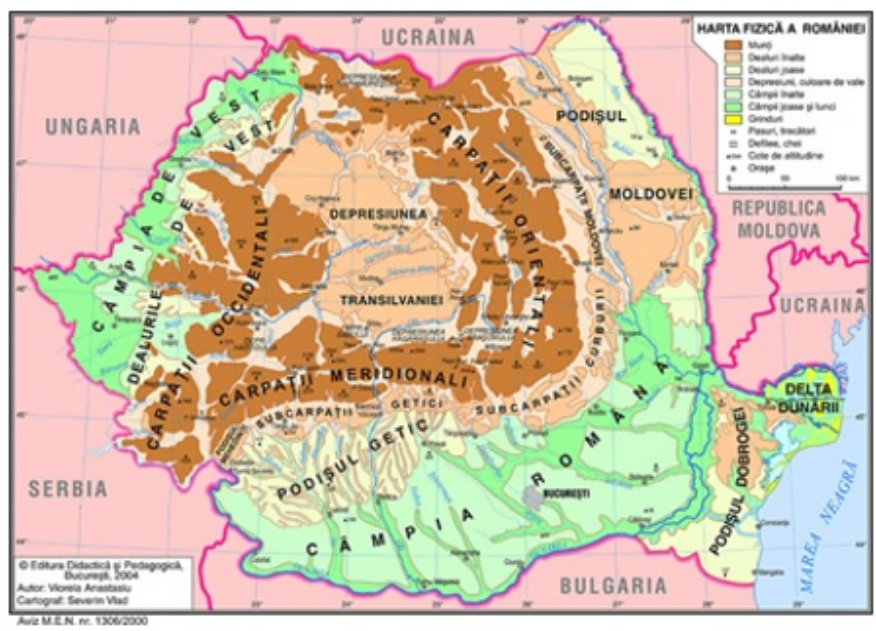

Fig. 1. Romania's geographical map

\section{Experimental part}

On the occasion of forest management plans, at an interval of 10 years for forest districts, soil samples from characteristic forest areas are gathered and analyzed (with a focus on $\mathrm{pH}$, humus content, carbonates content, basis exchange capacity (Sb), hydrogen exchange capacity (Sh), total cationic exchange capacity $(T)$, base degree saturation (V), texture, total nitrogen). Accredited national and international methods are used in the analysis of soil samples [9]. For the present paper, the soil samples gathered in the period 1985-2016 from the 12 forest districts

\footnotetext{
*email: cantar.cosmin@yahoo.com, Phone: +40771773018
} 
Tests of Normality

\begin{tabular}{|l|c|c|c|c|c|c|}
\hline & \multicolumn{3}{|c|}{ Kolmogorov-Smimov } & \multicolumn{3}{c|}{ Shapiro-Wilk } \\
\cline { 2 - 7 } & Statistic & $\mathrm{df}$ & Sig. & Statistic & df & Sig. \\
\hline $\mathrm{pH}$ eutric A & 0.068 & 31 & $0.200^{*}$ & 0.984 & 31 & 0.908 \\
\hline
\end{tabular}

is is a lower bound of the true significance.

a. Lilliefors Significance Correction

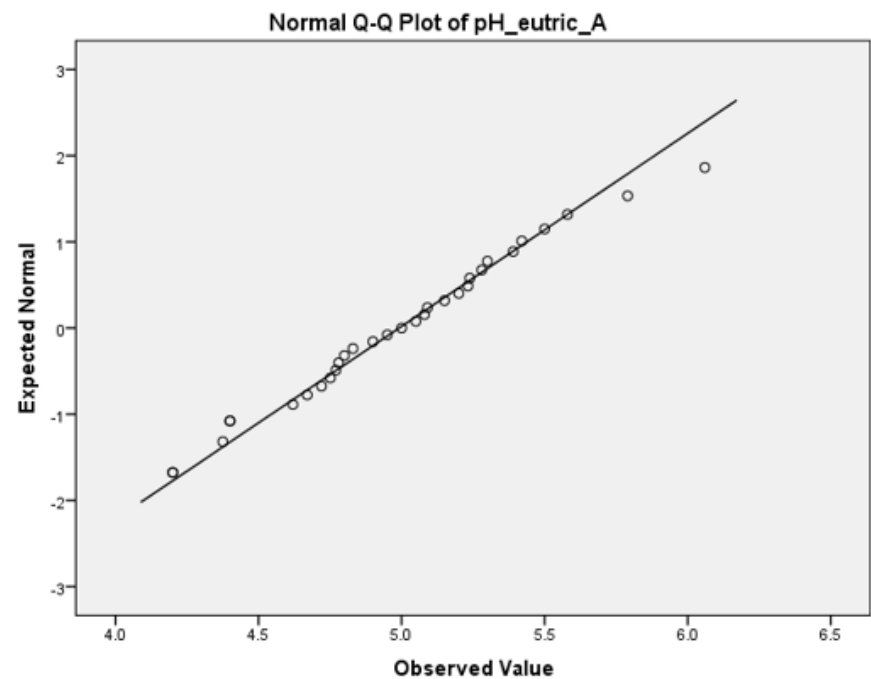

Fig. 2 Data distribution representing $\mathrm{pH}$ in the Ao horizon of eutric cambisol from the West Plain

situated in the West Plain were analyzed, namely 484 soil profiles and 1414 pedo-genetical horizons [10].

Average values were calculated for the soil's chemical properties, while the values were then differentiated on soil types and pedo-genetical horizons and distributed on normal curves. Furthermore, in order to verify the data, Kolmogorov-Smirnov and Shapiro-Wilk statistical tests were applied, by using the SPSS statistical program. An example concerning the testing of normal $\mathrm{pH}$ distribution in a eutric cambisol Ao horizon is rendered in table 1.

From a graphical point of view, the data distribution representing $\mathrm{pH}$ in a eutric cambisol Ao horizon from the West Plain is rendered in figure 2.

\section{Results and discussions}

\section{Soil solution reaction ( $\mathrm{pH}$ )}

The average $\mathrm{pH}$ value of all West Plain soils for the $\mathrm{A}$ horizon (generally situated at depths between 0 and 10 $\mathrm{cm}$ ) is of 5.46. For the B horizon (generally situated at depths between 10 and $90 \mathrm{~cm}$ ), the average $\mathrm{pH}$ value is of 5.65 , while for the $\mathrm{C}$ horizon (generally situated at depths between 90 and $120 \mathrm{~cm}$ ), the average $\mathrm{pH}$ value reaches 6.48. The highest $\mathrm{pH}$ values can be found in the case of phaeozem (neutral-weakly alkaline soil), followed by fluvisol (neutral soil), while preluvisol and luvisol are moderately acid soils. For all the West Plain soils, the $\mathrm{pH}$ grows on the soil's depth (fig. 3), a fact caused by the geological substratum composed of loess deposits.

Eutric cambisol is a soil prevalent in hill areas. However, he can also be found in plain or piedmont areas. By taking these aspects into consideration, the West Plain's soils pH is smaller than the one from hill or piedmont areas (Buzau [11], Harghita [12], Maramures [13]), as can be seen in table 2. Other authors have also observed that the eutric cambisol's pH increases with the altitude [14]. In the case of luvisol and preluvisol, these differences are not ascertained.

\section{Base saturation degree (V)}

Table 1

TESTING NORMAL DATA DISTRIBUTION IN THE A HORIZON OF EUTRICCAMBOSOL FROM THE WEST PLAIN

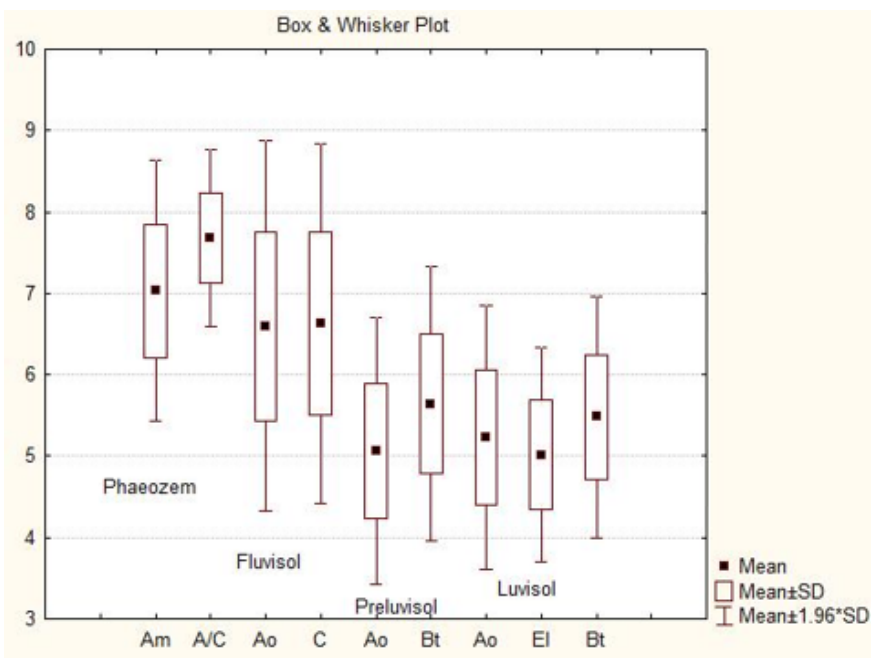

Fig. 3.pH variation of genetic horizons for the most widespread forest soils from the West Plain

Table 2

$p H$ VALUES OF FOREST SOILS FROM DIFFERENT REGIONS OF ROMANIA

\begin{tabular}{|l|l|l|l|l|l|l|l|}
\hline \multicolumn{1}{|c|}{ Area } & \multicolumn{2}{c|}{$\begin{array}{c}\text { Eutric } \\
\text { cambisol }\end{array}$} & \multicolumn{3}{c|}{ Luvisol } & \multicolumn{2}{c|}{ Preluvisol } \\
\hline & Ao & Bv & Ao & El & Bt & Ao & Bt \\
\hline West Plain & 4.99 & 5.33 & 5.23 & 5.01 & 5.48 & 5.06 & 5.64 \\
\hline Buzău County & 5.44 & 5.89 & 5.64 & 5.11 & 5.67 & 5.26 & 5.5 \\
\hline Harghita County & 5.17 & 5.69 & 5.01 & 4.83 & 5.23 & 5.46 & 5.77 \\
\hline Maramures County & 5.41 & 5.79 & 4.83 & 4.76 & 5.21 & 4.67 & 5.22 \\
\hline Neamt County & 5.6 & 6.09 & 5.37 & 5.05 & 5.7 & 5.04 & 5.85 \\
\hline
\end{tabular}

The following values were recorded for the average base saturation degree: $29.5 \%$ for the A horizon, $64.62 \%$ for the $\mathrm{B}$ horizon and $77.7 \%$ for the $\mathrm{C}$ horizon. The phaeozem is a eubasic soil (V>75\%), while all the other soils are mesobasic ( $V=52 \%-75 \%)$, as can be observed in figure 4 .

There is not a significant difference between the base saturation degree of soils from the West Plain and soils from similar plain areas of the country, table 3 .

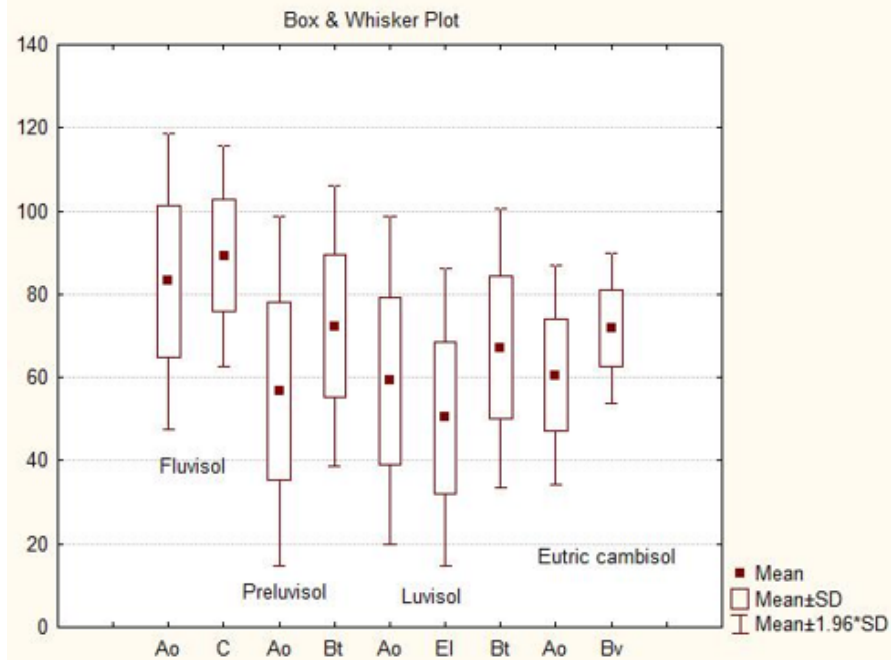

Fig. 4. Base saturation degree (V) variation of genetic horizons for the most widespread forest soils from the West Plain 


\begin{tabular}{|l|c|c|c|c|c|c|c|c|}
\hline \multicolumn{1}{|c|}{ Area } & \multicolumn{3}{c|}{ Phaeozem } & \multicolumn{3}{c|}{ Fluvisol } & \multicolumn{3}{c|}{ Luvisol } \\
\hline & Am & A/C & C & Ao & C & Ao & El & Bt \\
\hline West Plain & 90.13 & 98.87 & 99.87 & 83.14 & 89.22 & 59.24 & 50.37 & 67.19 \\
\hline Giurgiu County & 86.82 & 90.1 & 100 & 90.54 & 90.09 & 76.39 & 72.58 & 77.83 \\
\hline Botoșani County & 74.64 & 93.43 & 100 & 84.15 & 90.03 & 69.56 & 51.92 & 76.09 \\
\hline
\end{tabular}

Table 3

BASE SATURATION DEGREE FOR

FOREST SOILS FROM DIFFERENT

REGIONS OF ROMANIA (\%)
Total cationic exchange capacity $(T)$

The average value of the cation exchange capacity is of $23.92 \mathrm{me} / 100 \mathrm{~g}$ soil (for the A horizon), $23.19 \mathrm{me} / 100 \mathrm{~g}$ soil (for the B horizon) and $20.94 \mathrm{me} / 100 \mathrm{~g}$ soil (for the C horizon). Eutric cambisol, luvisol and preluvisol have a high total cationic exchange capacity ( $T=15-25 \mathrm{me} / 100 \mathrm{~g} \mathrm{sol})$, while fluvisol and phaeozem have a very high total cationic exchange capacity (T>25 $25 \mathrm{me} / 100 \mathrm{~g}$ sol), as can be seen in table 4 and figure 5 .

The T from the West Plain is similar with the one from other Romanian counties (Vaslui [15]), table 5.

\section{Humus content}

The average humus content values are as follows: 4.54\% for the A horizon, $1.66 \%$ for the B horizon and $1.07 \%$ for the Chorizon.

Due to the fact that the relevant humus quantity which varies between soil types is the one from the first horizon, average values for it were calculated for different types of soils from the analyzed area (fig. 6). As such, soils from this region are moderately humiferous (humus $=2-5 \%$ ).

Similar humus values were also found at the country's level for phaeozem and eutric cambisol [16]. However,

\begin{tabular}{|c|c|c|c|c|}
\hline Fluvisol & Phaeozem & Eutric cambisol & Luvisol & Preluvisol \\
\hline \multicolumn{5}{|c|}{$\mathrm{pH}$} \\
\hline 6.62 & 7.48 & 5.2 & 5.25 & 5.45 \\
\hline \multicolumn{5}{|c|}{ Base saturation degree (\%) } \\
\hline 86.26 & 93.09 & 67.47 & 59.37 & 62.24 \\
\hline \multicolumn{5}{|c|}{ Total average cationic exchange capacity per soil type (T-me/100 g sol) } \\
\hline 26.75 & 27.55 & 19.08 & 24.51 & 24.18 \\
\hline \multicolumn{5}{|c|}{ Average humus content in the $\mathrm{A}$ horizon per soil type (H-\%) } \\
\hline 3.09 & 2.77 & 2.98 & 2.88 & 2.67 \\
\hline \multicolumn{5}{|c|}{ Average nitrogen content in the $A$ horizon per soil types (\%) } \\
\hline 0.17 & 0.19 & 0.15 & 0.15 & 0.13 \\
\hline
\end{tabular}

Table 4

AVERAGE HUMUS, NITROGEN AND TOTAL CATIONIC EXCHANGE CAPACITY CONTENT ON THE ENTIRE SOIL PROFILEFOR FOREST SOILS FROM THE WEST PLAIN

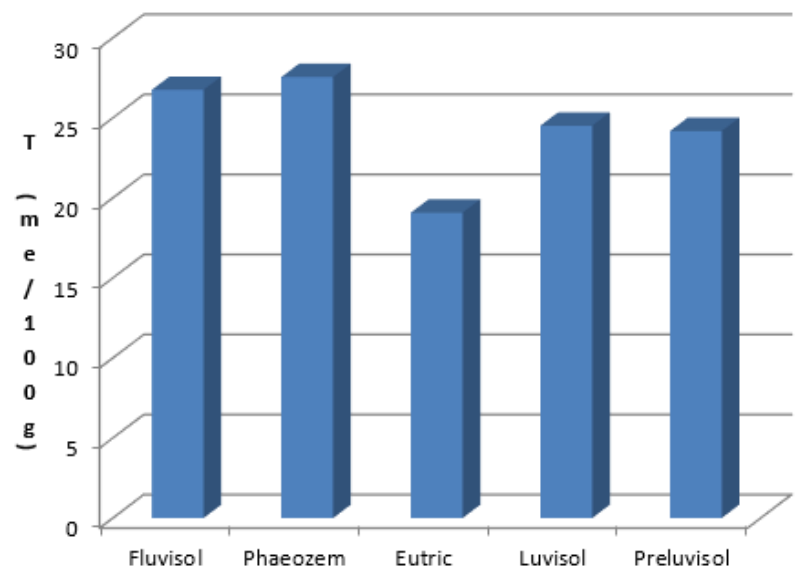

Fig. 5. The variation of total catiohice exchange capacity for the most widespread forest soils from the West Plain

Table 5

TOTAL CATIONIC EXCHANGE CAPACITY OF FOREST SOILS FROM DIFFERENT REGIONS OF ROMANIA (ME/100 g OF SOIL)

\begin{tabular}{|l|l|l|l|l|}
\hline \multicolumn{1}{|c|}{ Area } & Phaeozem & $\begin{array}{c}\text { Eutric } \\
\text { cambisol }\end{array}$ & Luvisol & Preluvisol \\
\hline West Plain & 27.55 & 19.08 & 24.51 & 24.18 \\
\hline Botoșani County & 23.37 & 21.72 & 21.9 & 18.14 \\
\hline Vaslui County & 22.78 & 21.89 & 21.15 & 20.68 \\
\hline Cluj County & 29.71 & 24.65 & 21.42 & 23.7 \\
\hline Neamț County & 28.33 & 24.49 & 23.1 & 21.9 \\
\hline
\end{tabular}

they were lower in the case of luvisol and preluvisol (table $6)$. The humus quantity registered for eutric cambisol is similar with the one at the country's level or from Vaslui, but it is lower than all the studied counties. This is caused by the fact that eutric cambisols from the Wes Plain are situated at lower altitudes. On the other hand, the preluvisols humus has very high values in the West Plain, due to the climate, which is favorable for more productive forest stands.

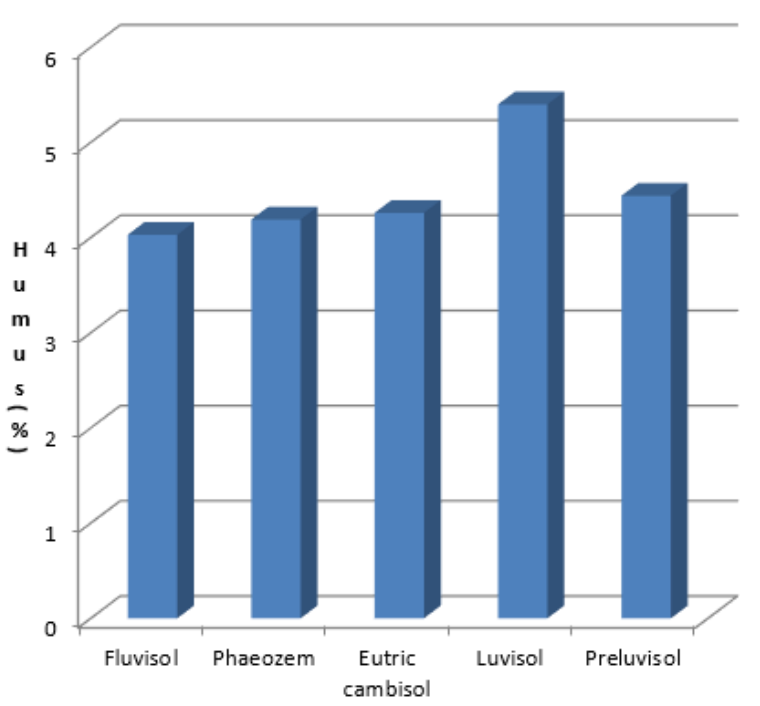

Fig. 6. The variation of humus content in A horizon for the most widespread forest soils from the West Plain

Table 6

HUMUS CONTENT FOR FOREST SOILS FROM DIFFERENT REGIONS OF ROMANIA (\%)

\begin{tabular}{|l|l|l|l|l|}
\hline \multicolumn{1}{|c|}{ Area } & Phaeozem & $\begin{array}{c}\text { Eutric } \\
\text { cambisol }\end{array}$ & Luvisol & Preluvisol \\
\hline West Plain & 4.19 & 4.26 & 5.4 & 5.06 \\
\hline Románia & 3.95 & 4.53 & 3.61 & 2.93 \\
\hline Botoșani County & 4.69 & 6.24 & 5.9 & 4.9 \\
\hline Vasiui County & 3.68 & 4.08 & 4.81 & 4.0 \\
\hline Buzău County & 5.7 & 5.61 & 5.87 & 4.99 \\
\hline Cluj County & 5.58 & 4.56 & 4.3 & 4.1 \\
\hline Harghita County & 4.67 & 6.57 & 4.98 & 4.01 \\
\hline Neamț County & 6.22 & 6.79 & 7.0 & 5.22 \\
\hline
\end{tabular}




\section{Total nitrogen}

The average nitrogen content values are as follows: $0.238 \%$ for the $A$ horizon, $0.085 \%$ for the $B$ horizon and $0.056 \%$ for the $C$ horizon. As such, soils from this area are well supplied with nitrogen $(\mathrm{N}=0.2-0.28 \%$ in the first horizon). Similar values of nitrogen content $(0.201 \%)$ have been also identified on ash and slag deposit from Utvin (Timisoara) [17].

\section{Conclusions}

Forest soils from the Romania's West Plain are soils characteristic to the plain area. As such, they are moderately acid, neutral up to weakly alkaline, have an average $p \mathrm{H}$ of 5.46, are mesobasic up to eubasic, with a total cationic exchange capacity ranging from high to very high, are moderately humiferous and well supplied with nitrogen.

Some soil types appear in many geographical and geomorphological areas of Romania and have different chemical properties due to the differentiation caused by altitude and geological substratum. In the case of forest soils from the West Plain, a lower $\mathrm{pH}$ than other hill and piedmont areas was observed together with lower values of humus for eutric cambisol and higher for preluvisol.

In regard with the base saturation degree, significant differences were observed between the soils from the West Plain and similar soils from other Romanian field areas. The humus quantity for eutric cambisols is lower in the West Plain that other counties, due to the lower altitude at which eutric cambisols can be found. As for total nitrogen, it can be observed that the soils from the West Plain are well supplied with this mineral.

\section{References}

1.CRACIUNESCU, A., Impaduriri în Campia de Vest, Seria Lucrari de cercetare, Editura Silvica, Bucharest, 2014, 4 p.

2.SHARMA, A., WEINDORF, D. C., MAN, T., ALDABAA, A. A. A., CHAKRABORTY, S., Geoderma, 232, 2014, p. 141.
3.DINU, C., UNGUREANU, E.M., VASILE, G.G., KIM, L., IONESCU, I., ENE, C., SIMION, M, Rev. Chim. (Bucharest), 69, no. 1, 2018, p. 14.

4.BACHE, B.W., Base saturation. In: Encyclopedia of Soil Science, Springer, Netherlands, 2008, $52 \mathrm{p}$.

5.RHOADES, J. D., Cation Exchange Capacity 1. In: Methods of soil analysis. Part 2. Chemical and microbiological properties, Publisher American Society of Agronomy, Crop Science Society of America and Soil Science Society of America, Wisconsin, 1982, 149 p.;

6.STEVENSON, F. J., Bioscience, 22, no. 11, 1972, p. 643;

7.STEVENSON, F. J., Organic forms of soil nitrogen. In: Methods of soil analysis. Part 2. Chemical and microbiological properties second edition, Publisher American Society of Agronomy, Crop Science Society of America and Soil Science Society of America, Wisconsin, 1982, 67 p.

8.MULVANEY, R. L., Nitrogen-in organic forms. In: Methods of soil analysis part 3 -Chemical methods, Publisher Soil Science Society of America and American Society of Agronomy, 1996, p. 1123;

9.DINCA, L., LUCACI, D., IACOBAN C., IONESCU M., Analysis methods for soil solution and properties (Metode de analiza a proprietatilor si solupiei solurilor), Editura Tehnica Silvica, 2012, 173 p.

10. *** Forest management plans belonging to Carei (1998, 2008, 2013), Ceala (1992, 2002, 2012), Chisinau Cris (2002, 2012), Lipova (2007), Livada (1992, 2002, 2012), Lunca Timisului (2008), Oradea (2007), Radna (2006, 2015), Satu Mare (1992, 2004, 2014), Sãcuieni (1988, 2008), Timisoara (1988, 1998, 2008), Tinca (1988, 1998, 2008);

11.CRISAN, V.E., ENESCU, R.E., BRAGA, C., J ournal of Horticulture, Forestry and Biotechnology, 21, no. 4, 2017, p.142;

12.ENESCU, R.E., DINCA L., LUCACI, D., ProEnvironment Promediu, 10, no. 30, 2017, p. 57;

13.CRISAN, V.E., ENESCU, R.E., DINCA, M., Silviculture and Hunting Magazine (Revista de Silvicultura si Cinegetica), 39, 2016, p. 85;

14.SPARCHEZ, G., DINCA, L., MARIN, G., DINCÃ, M., ENESCU, R.E., Environ. Eng. Manag. J., 16, no. 12. , 2017, p. 2911;

15.DINCA, M., CADAR, N., J ournal of Horticulture, Forestry and Biotechnology, 21, no. 1, 2017, p. 23;

16.DINCA, L. C., DINCA, M., VASILE, D., SPARCHEZ, GH., HOLONEC, L., Not Bot Horti Agrobot Cluj Napoca, 43, no. 2, 2015, p. 568jou; 17.NICORESCU, V., MASU, S., ANDRES, L., PASCU, L.F., VLAICU, I., BOZAN, C., HOLLERBACH, W., TRAVA, I.D., Rev. Chim. (Bucharest), 69, no. 1, 2018, p. 45.

Manuscript received: 6.06 .2018 